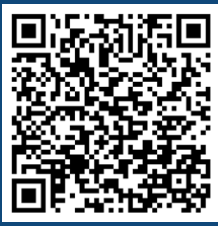

Keywords:

Mycorrhizal association

Fava-de-bolota

Inoculation

Water condition

Historic:

Received 17/10/2019

Accepted 21/01/2020

Correspondence:

adrianamsarauco@gmail.com
Dayara Lins Porto', Adriana Miranda de Santana Arauco'+, Cácio Luiz Boechat', Adriano de Oliveira Silva', Mara Regina Moitinho², Séfora Gil Gomes de Farias'

\section{ARBUSCULAR MYCORRHIZAL FUNGI ON THE INITIAL GROWTH AND NUTRITION OF Parkia Platycephala BENTH. UNDER WATER STRESS}

PORTO, D. L.; ARAUCO, A. M. S.; BOECHAT, C. L.; SILVA, A. O.; MOITINHO, M. R.; FARIAS, S. G. G. Arbuscular mycorrhizal fungi on the initial growth and nutrition of Parkia platycephala Benth. under water stress. CERNE, v. 26, n. I, p.66-74, 2020.

\section{HIGHLIGHTS}

Plants with water stress presented a lower absorption of macro and micronutrients in relation to the condition without stress.

Mycorrhizal fungi favored plant growth as well as the absorption of nutrients.

The mycorrhizal colonization rate of $P$. platycephala was influenced by AMF regardless of water conditions.

\section{ABSTRACT}

Parkia platycephala Benth. (Fava-de-bolota) found in areas of Cerrado-Caatinga transition, is a species with potential for feeding ruminants in arid regions. The objective of this study was to evaluate the effect of inoculation of arbuscular mycorrhizal fungi (AMF) on the initial growth and nutrition of $P$. platycephala Benth. seedlings under water stress. The experimental design was a randomized block design in a $2 \times 6$ factorial scheme with five replications, consisting of two water regime conditions (with and without stress), four AMF strains (Gigaspora rosea, Gigaspora margarita, Acaulospora koskei, and Acaulospora morrowiae), one treatment with associated inoculum (Mix), and one control. At I 20 days after sowing, the morphological variables height $(H)$, stem diameter (SD), number of leaves $(\mathrm{NL})$, root length (RL), total root volume (TRV), shoot dry mass (SDM), root dry mass (SDM) and total dry mass (TDM) were evaluated. Nutrient contents and mycorrhizal colonization rate were also evaluated. The variables NL, SDM and TDM presented significant interaction between inoculation with the fungi and the studied water conditions. For the contents of $\mathrm{P}, \mathrm{Mg}$ and $\mathrm{Mn}$ there was also interaction, being the best results with the strains A. koskei, Mix, A. morrowiae and control, respectively, in the condition without water stress. Mycorrhizal fungi favored plant growth as well as the absorption of $\mathrm{P}, \mathrm{Mg}, \mathrm{Mn}$ and $\mathrm{Zn}$.
' Federal University of Piaú,, Bom Jesus, Piaú, Brazil- ORCID: 0000-0003-1497-0297ª, 0000-0002-2538-777X 0000-0002-5086-9I56c, 0000-000 I-8480-6404 d , 0000-0002-9878-4653

2 Brazilian Biorenewables National Laboratory (LNBR), Brazilian Center for Research in Energy and Materials, Campinas, São Paulo, Brazil. ORCID: 0000-0002-940 I-6294 


\section{INTRODUCTION}

Cerrado is the second largest biome in South America, occupying an area of approximately 2 million $\mathrm{km}^{2}$, which corresponds to $23.92 \%$ of the Brazilian territory, while the Caatinga biome occupies an area of $800,000 \mathrm{~km}^{2}$, equivalent to $9.92 \%$ of the territory, both showing a rich and vast biodiversity, with the main Brazilian forest formations (Oliveira et al., 20 I2; Instituto Brasileiro de Geográfica e Estatística, 2004; Food and Agriculture Organization, 2005; Ministério do Meio Ambiente, 2018).

Among the several species of trees in these biomes is the Parkia platycephala Benth., a tree legume with good qualities for afforestation and pods usually used in forage for feeding ruminants (Lorenzi, 2002) in scarcity periods. In the literature there are few information known on the adaptive characteristics and environmental conditions since water stress in periods of more severe droughts cause physiological and morphological changes to plants (Pelegrini et al., 2013) by reducing their metabolic activity and causing deficiency in the translocation of mineral nutrients, affecting growth and productivity (Silveira et al., 2016).

Arbuscular mycorrhizal fungi (AMF) have marked and consistent effects on plant growth, especially under conditions of soil nutrient deficiency and water stress (Faria et al., 20I3). AMF are obligate biotrophic organisms, which establish symbiosis with roots of most terrestrial plants, working as an expansion of the plant root system and providing a higher water and nutrient absorption (Silva et al., 2004). According to Farias et al. (2008) and Soares and Carneiro (20I0), plants produce a higher amount of root dry matter when inoculated with AMF, favoring their adaptation and survival in an environment under stress.

AMF increase nutrient absorption, especially phosphorus $(\mathrm{P})$, due to their mycorrhizal activity (Brito et al., 2017). In addition to improving nutritional status, AMF increase the tolerance to root diseases (Borges et al., 2007), accelerate growth, improve seedling vigor in their formation phase (Nunes et al., 2008; Soares et al., 20I2), and contribute to the formation and maintenance of soil structure by aggregating soil particles by extra-radicular hyphae through exudates and residues (Folli-Pereira et al., 2012).

In this context, the hypothesis of this study is that the association of mycorrhizal fungi with the tree species acorn bean positively influences plants submitted to water stress conditions. Thus, considering that this association provides an expansion of the root system, favoring higher water and nutrient absorption, this study aimed to assess the effect of inoculating arbuscular mycorrhizal fungi on the initial growth and nutrition of $P$. platycephala Benth. under water stress, and this way contributing with information on quality seedling production of this species in transition areas of the Cerrado and Caatinga biomes.

\section{MATERIAL AND METHODS}

\section{Study location}

The experiment was conducted in a greenhouse located in the Brazilian semi-arid region at the geographical coordinates $09^{\circ} 04^{\prime} \mathrm{S}$ and $44^{\circ} 2 \mathrm{I}^{\prime} \mathrm{W}$, with $277 \mathrm{~m}$ of average altitude. According to Koppen, regional climate is classified as Aw, i.e. a tropical warm and humid climate with two well-defined seasons: a dry season from May to October and a rainy season from November to April (Medeiros et al., 2016).

\section{Soil preparation}

The soil used in the experiment was classified as Quartzipsamment (Neossolo Quartzarênico Órtico típico, Brazilian Soil Classification System) (Santos et al., 20/3). Soil samples were collected at a depth of $0-20 \mathrm{~cm}$ and submitted to physicochemical analysis according to the methodology described by Silva (2009). The average values of these soil attributes are shown in Table I.

Before the experiment setup, the soil was airdried, decloded, sieved in a $2 \mathrm{~mm}$ mesh sieve, and packed in fiber bags to be autoclaved at $121{ }^{\circ} \mathrm{C}$ and at I atm for 30 minutes. Black PVC pots with a $3 \mathrm{~L}$ capacity were drilled in the bottom and filled with $400 \mathrm{~g}$ of rock fragments to facilitate water flow. These rocks were covered with a fabric and $3 \mathrm{~kg}$ of soil were added. This soil was corrected according to the recommendations of soil corrective for the Cerrado biome, raising base saturation to $50 \%$ (Sousa and Lobato, 2004), with the incorporation of dolomitic limestone with the following composition: $32 \% \mathrm{CaO}, 47 \% \mathrm{CaO}+\mathrm{MgO}, 15 \% \mathrm{MgO}$, $\mathrm{CaCO} 3$ band $\mathrm{A}, 94.5 \%$ neutralizing power, $91 \%$ relative power of total neutralization, and moisture of $3 \%$. No chemical fertilization was performed in this soil.

\section{Species under study and seed preparation}

Seeds from P. platycephala Benth. were donated, being collected from 15 matrix trees in native area, free from pathogens and injuries were selected and then submitted to mechanical scarification to overcome the integumentary dormancy and treated with $5 \%$ sodium hypochlorite solution, according to procedures by Silva et al. (2017).

\section{Experimental Design}

The experimental design was a randomized block design arranged in a $2 \times 6$ factorial scheme, which consisted of two water regime conditions (with and without stress) and six inoculation treatments, with five replications. Treatments consisted of the isolated strains Gigaspora rosea SPL I0IA, Gigaspora margarita SCT 
TABLE I Descriptive statistics of the data groups.

\begin{tabular}{|c|c|c|c|c|c|c|c|c|c|}
\hline $\begin{array}{c}\mathrm{pH} \\
(\mathrm{H}, \mathrm{O})\end{array}$ & $\mathrm{H}+\mathrm{Al}$ & $\mathrm{Al}$ & $\mathrm{Ca}$ & $\mathrm{Mg}$ & $\mathrm{Ca}+\mathrm{Mg}$ & K & SB & CEC & P \\
\hline & & & 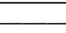 & cmolc & $\mathrm{c} \mathrm{dm}^{-3}$ & & & - & $\mathrm{ng} \cdot \mathrm{dm}^{-}$ \\
\hline 4.6 & 3.47 & 0.2 & 0.53 & 0.13 & 0.66 & 0.1 & 0.77 & 4.23 & 1.75 \\
\hline $\mathrm{Cu}$ & $\mathrm{Fe}$ & $M n$ & $\mathrm{Zn}$ & V & $\mathrm{m}$ & SOM & Clay & Silt & Sand \\
\hline & $-\mathrm{mg} \cdot \mathrm{dn}$ & $1^{-3}$ & & & $-\%$ & & $-g \cdot k$ & $\mathrm{~kg}^{-1}$ & $\overline{5}$ \\
\hline 0.97 & 85.37 & 7.13 & 1.75 & 18.1 & 20.7 & 6 & 69 & 11 & 920 \\
\hline
\end{tabular}

077A, Acaulospora koskei SCT 042A, and Acaulospora morrowiae SCT 048B, a consortium of strains (mix of the four strains), and a control (without inoculation).

Planting and inoculation of arbuscular mycorrhizal fungi (AMFs)

Planting was carried out manually using 5 seeds per pot. The inoculation was performed with $5 \mathrm{~g}$ of AMF of the 4 individual strains and I.25 g of AMF of each strain for the consortium (Mix). After the complete emergence, thinning was carried out and only two visually more vigorous seedlings remained per experimental unit.

The arbuscular mycorrhizal fungi (AMFs) strains used were provided by the International Glomeromycota Culture Collection (CICG) of the Regional University of Blumenau (FURB), Blumenau, Santa Catarina, Brazil.

\section{Water stress application}

For water stress, soil moisture was maintained around $60 \%$ of the pot capacity, being determined by the water content removed from soil after saturation, by capillarity, until the drainage is finished. Irrigation of pots was controlled by means of periodic weighings, using a precision balance with a capacity of $10 \mathrm{~kg}$, followed by the replacement of the evapotranspirated water in the period and keeping the pots close to field capacity.

Water stress was applied in treatments by suspending the daily irrigation both with 30 plants. Plants under water stress underwent three periods without irrigation. The days under water stress were defined according to leaf rolling and plant growth. The other plants were irrigated to maintain soil moisture close to $60 \%$ of the pot capacity. Irrigation was suspended for the first time at 35 days after sowing for 12 days, for the second time at 70 days after sowing for nine days, and for the third time at 105 days after sowing for seven days.

\section{Evaluation}

\section{Growth}

The following biometric analyses were performed at 120 days after sowing (end of the experiment): plant height (HP) with a measuring tape, stem diameter (SD) with a digital caliper, root length (RL) with a measuring tape, and the number of leaves $(\mathrm{NL})$ by counting. Roots were washed in running water to remove the adhered material and then the following variables were measured: shoot dry matter (SDM), root dry matter (RDM), total dry matter (TDM), mycorrhizal colonization rate (MC), and total root volume (TRV), which was obtained using the methodology proposed by Peixoto et al., (2010), in which the roots are immersed in water in a measuring cylinder, being observed the displaced volume of water. Seedlings were separated into roots and shoot and taken to a forced air circulation oven at $65^{\circ} \mathrm{C}$ until constant weight in order to assess the dry mass. Subsequently, the material was weighed to determine RDM and SDM.

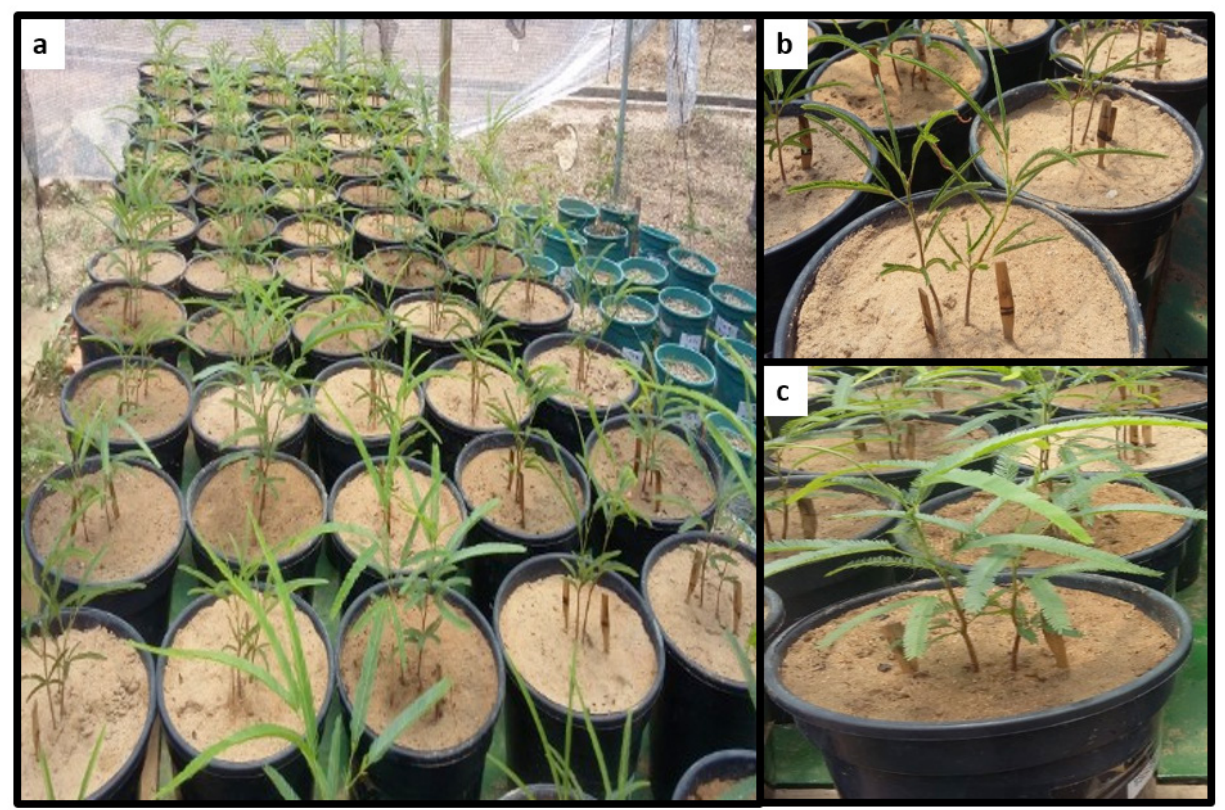

FIGURE I Overview of treatments with different water regimes (a), water stress treatment (b), treatment without water stress (c). 


\section{Mycorrhizal colonization rate}

The mycorrhizal colonization rate was assessed according to the methodology proposed by Koske and Gemma (1989). For this, I $g$ of fresh fine roots were weighed and then clarified and pigmented. Fungal structures were counted by the gridline intersection procedure proposed by Giovannetti and Mosse (1980).

\section{Nutritional contents}

The contents of macro and micronutrients ( $P$, $\mathrm{K}, \mathrm{Ca}, \mathrm{Mg}, \mathrm{S}, \mathrm{Cu}, \mathrm{Fe}, \mathrm{Mn}$, and $\mathrm{Zn}$ ) of plant shoot were determined according to the methodology described in Silva (2009). For this, the nutrient extraction method by means of the wet digestion by nitric $(65 \%)$ and perchloric acid $(72 \%)$ was used.

\section{Data analysis}

The data were submitted to the F-test by means of analysis of variance (ANOVA). When significant, the means were submitted to the Scott-Knott test at $5 \%$ of probability, being the data of the mycorrhizal colonization rate and manganese content transformed into square root of $x+1$. Simultaneously with the statistical analyses, the basic assumptions of ANOVA, normality of errors, and homogeneity of variances were tested for all the analyzed variables. All the procedures performed were conducted in the software R ( $R$ Core Team, 20I6).

\section{RESULTS AND DISCUSSION}

\section{Biometric and morphological parameters}

The number of leaves (NL) presented a significant interaction between fungal species and conditions (with and without stress). The NL was significantly higher in the condition stress without. Only treatments with the inoculum $G$. rosea and the Mix showed no significant difference due to the water conditions of the soil (Table 2).

A similar result was observed by Martins et al. (2008) evaluating water stress in two species of eucalyptus observed that the number of leaves were affected in response to the reduction of water in the soil, which indicates that the stress should affect the metabolism of the plant and cause a decrease in the growth and development of the seedlings.

According to Couto et al. (2009), NL is considered one of the most important characteristics for seedling transplanting in the field, i.e. the higher the number of leaves the plants have, the higher is their establishment in the field since they are structures responsible for capturing solar energy by photosynthesis and producing organic matter.

Mazzuchelli et al. (20/4) attribute that in order to make plants more resistant to variations in environmental conditions and the need to perform seedling rustification, because in this process the effect of water stress induced by water suspension can give a prediction of how plants respond to stress in adverse conditions in the field.

Regardless of the inoculation, plants of $P$. platycephala showed a reduction in height $(\mathrm{HP})$ and stem diameter (SD) when submitted to water stress (Table 2), indicating a detrimental effect in these variables with a reduction in the water regime. These variables are important because they are associated with dry matter production. Thus, water stress may have interfered with growth variables (height, stem diameter, and number of leaves). Matos et al. (20I8a) and Matos et al. (20l8b) assessed height, stem diameter, and number of leaves in plants of Tectona grandis and Dipteryx alata and observed a marked reduction in their vegetative growth when submitted to different levels of water stress. These authors reported that water stress could directly affect plant growth variables, reducing cell expansion, cell wall formation, and carbohydrate availability, which influence the production of growth regulators.

In this sense, the water stress applied to seedlings of $P$. platycephala resulted in lower water availability for cell expansion and plant metabolism, leading to low plant growth (Table 2). In addition, no significant difference ( $p>0.05$ ) was observed for root length (RL) and total root volume (TRV) when treatments and water condition were assessed (Table 2).

The joint application of the studied water condition and AMF may result in a positive synergic effect on root dry matter (RDM) and total dry matter (TDM) in the plants (Table 3). The parameters RDM and TDM presented a significant interaction between mycorrhizal fungal strains and the condition with and without water stress (Table 3). Plants presented a difference in RDM and TDM when both water conditions were assessed in the strains $A$. morrowiae and $G$. rosea and in the inoculum Mix. Under the condition without water stress, the inoculation with the strain $A$. morrowiae provided a significant effect for RDM, with an average value of 0.40 $\mathrm{g}$, differing from the other treatments. Regarding TDM, also under the condition without stress, the strains $A$. morrowiae and $G$. rosea and the inoculum Mix presented the highest average values, i.e. I.37, I.20, and $1.10 \mathrm{~g}$, respectively (Table 3). 
TABLE 2 Average values of biometric variables of seedlings of Parkia platycephala inoculated with arbuscular mycorrhizal fungi (AMF) under water stress.

\begin{tabular}{|c|c|c|c|c|c|c|c|c|c|c|c|c|c|c|c|}
\hline \multirow[t]{2}{*}{ Fungus } & \multicolumn{3}{|c|}{ HP } & \multicolumn{3}{|c|}{ SD } & \multicolumn{3}{|c|}{ NL } & \multicolumn{3}{|c|}{$\mathrm{RL}$} & \multicolumn{3}{|c|}{ TRV } \\
\hline & $\mathrm{S}(\mathrm{I})$ & WS(2) & Mean & $S$ & WS & Mean & $S$ & WS & Mean & $S$ & WS & Mean & $\mathrm{S}$ & WS & Mean \\
\hline & \multicolumn{3}{|c|}{ - cm - } & \multicolumn{3}{|c|}{---------- mm --------- } & \multicolumn{3}{|c|}{----- leaves plant ${ }^{-1}$} & \multicolumn{3}{|c|}{-------- cm --------- } & \multicolumn{3}{|c|}{---------- mL ---------- } \\
\hline Control & 16.7 & 19.0 & 17.8 & 2.1 & 2.3 & 2.2 & $5.9 \mathrm{Bb}$ & 6.9Aa & 6.4 & 25.2 & 25.7 & 25.4 & 1.0 & 1.0 & 1.0 \\
\hline A. koskei & 17.9 & 20.2 & 19.0 & 2.3 & 2.5 & 2.4 & $5.5 \mathrm{Bb}$ & $6.6 \mathrm{Aa}$ & 6.1 & 25.9 & 28.2 & 27.0 & 1.0 & 1.8 & 1.4 \\
\hline A. morrowiae & 17.9 & 25.3 & 21.6 & 2.1 & 2.8 & 2.4 & $6.2 \mathrm{Bb}$ & $7.5 \mathrm{Aa}$ & 6.9 & 27.2 & 26.2 & 26.7 & 1.1 & 0.83 & 0.96 \\
\hline G. margarita & 17.4 & 18.9 & 18.1 & 2.2 & 2.5 & 2.5 & $5.7 \mathrm{Bb}$ & $6.8 \mathrm{Aa}$ & 6.2 & 27.8 & 28.7 & 28.3 & 0.8 & 1.0 & 0.91 \\
\hline G. rosea & 18.8 & 21.8 & 20.2 & 2.3 & 2.4 & 2.3 & 7.3Aa & 7.3Aa & 7.3 & 27.8 & 25.7 & 26.7 & 1.2 & 1.4 & 1.3 \\
\hline Mix & 17.2 & 21.9 & 19.5 & 2.0 & 2.4 & 2.2 & $6.3 \mathrm{Ba}$ & $6.5 \mathrm{Aa}$ & 6.4 & 24.9 & 26.3 & 25.6 & 0.76 & 0.8 & 0.78 \\
\hline Mean & $17.6 \mathrm{~b}$ & $21.2 \mathrm{a}$ & & $2.2 \mathrm{~b}$ & $2.5 \mathrm{a}$ & & 6.2 & 6.9 & & 26.5 & 26.8 & & 0.98 & 1.1 & \\
\hline \multicolumn{16}{|c|}{$\mathrm{F}$ (analysis of variance) } \\
\hline $\begin{array}{l}\text { Fungus } \\
\text { (F) }\end{array}$ & \multicolumn{3}{|c|}{$1.94 \mathrm{~ns}$} & \multicolumn{3}{|c|}{$1.9 \mathrm{~ns}$} & \multicolumn{3}{|c|}{$2.28 \mathrm{~ns}$} & \multicolumn{3}{|c|}{$0.75 \mathrm{~ns}$} & \multicolumn{3}{|c|}{$1.83 \mathrm{~ns}$} \\
\hline $\begin{array}{c}\text { Condition } \\
\text { (C) }\end{array}$ & \multicolumn{3}{|c|}{$16.83 * *$} & \multicolumn{3}{|c|}{$28.48^{* * *}$} & \multicolumn{3}{|c|}{$36.12^{* * *}$} & \multicolumn{3}{|c|}{$0.12 \mathrm{~ns}$} & \multicolumn{3}{|c|}{$0.78 \mathrm{~ns}$} \\
\hline $\mathrm{F} \times \mathrm{C}$ & \multicolumn{3}{|c|}{$1.07 \mathrm{~ns}$} & \multicolumn{3}{|c|}{$0.08 \mathrm{~ns}$} & \multicolumn{3}{|c|}{$2.82 *$} & \multicolumn{3}{|c|}{$0.44 n s$} & \multicolumn{3}{|c|}{$0.6 \mathrm{Ins}$} \\
\hline CV Fungus (\%) & \multirow{2}{*}{\multicolumn{3}{|c|}{16}} & \multirow{2}{*}{\multicolumn{3}{|c|}{$\frac{10}{8}$}} & \multirow{2}{*}{\multicolumn{3}{|c|}{$\frac{14}{8}$}} & \multirow{2}{*}{\multicolumn{3}{|c|}{$\frac{14}{14}$}} & \multirow{2}{*}{\multicolumn{3}{|c|}{$\frac{52}{68}$}} \\
\hline CV Condition (\%) & & & & & & & & & & & & & & & \\
\hline
\end{tabular}

${ }^{(1)}$ With stress; ${ }^{(2)}$ without stress. HP = plant height; $\mathrm{SD}=$ stem diameter; $\mathrm{NL}=$ number of leaves; $\mathrm{RL}=$ root length; $\mathrm{TRV}=$ total root volume; $\mathrm{CV}$ $=$ coefficient of variation. Means followed by the same uppercase letter in the column and lowercase letter in the row do not differ from each other by Scott-Knott test at $5 \%$ probability.

Under the condition without water stress, plants had higher values of SDM regardless of the treatment (Table 3). This same behavior was found by Farias et al. (2008) when assessing plants of Moringa oleifera Lam., in which the water stress effect may have contributed to a reduction in shoot dry matter of plants influenced by leaf abscission. According to Taiz et al. (2017), a lower soil water availability can lead plants to water stress, causing morphological and physiological changes and, consequently, a lower dry matter gain by plants, reduction in cell expansion and leaf area, and a decrease in the root to shoot biomass ratio.

Sugai et al. (20I I) in similar studies evaluating the growth of Anadenanthera macrocarpa (Benth.) Brenan seedlings under the effect of inoculation of arbuscular mycorrhizal fungi (AMFs) in preserved and anthropized soil, warned favorable results in plant growth, as well as in the nutritional part of the plant with the inoculation of different species of AMFs, regardless of the soil used. Since, the AMFs, play a fundamental role in the maintenance of forest systems, which can assist in the absorption of nutrients from the soil and directly influence the growth of plants.

\section{Mycorrhizal colonization rate}

The colonization rate reached $23.3 \%$ with the inoculation of the strain $A$. morrowiae (Figure 2). The percentage of mycorrhizal colonization in roots of plants of $P$. platycephala was influenced by AMF regardless of the studied water condition. The strains $A$. morrowiae, G. margarita, and $G$. rosea and the Mix differed $(p<0.05)$ from $A$. koskei and control (without inoculation), but did not differ from each other. The strain A. koskei and control did not differ from each other, being less efficient regarding the mycorrhizal colonization rate in relation to the others (Figure 2).
TABLE 3 Average values of morphological variables of seedlings of Parkia platycephala inoculated with arbuscular mycorrhizal fungi (AMF) under water stress.

\begin{tabular}{|c|c|c|c|c|c|c|c|c|c|}
\hline \multirow{2}{*}{ Fungus } & \multicolumn{2}{|c|}{ SDM } & \multicolumn{3}{|c|}{ RDM } & \multicolumn{3}{|c|}{ TDM } & \multirow{2}{*}{ Mean } \\
\hline & $S(I)$ & WS(I) & & $S$ & WS & Mean & $\mathrm{S}$ & WS & \\
\hline \multicolumn{10}{|c|}{ 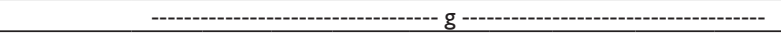 } \\
\hline Control & 0.46 & 0.78 & 0.62 & $0.15 \mathrm{Aa}$ & $0.22 \mathrm{Ba}$ & 0.19 & $0.6 \mathrm{IAa}$ & $0.66 \mathrm{Ba}$ & 0.64 \\
\hline A. koskei & 0.58 & 0.77 & 0.68 & $0.2 \mathrm{IAa}$ & $0.28 \mathrm{Ba}$ & 0.24 & $0.79 \mathrm{Aa}$ & $0.85 \mathrm{Ba}$ & 0.82 \\
\hline A. morrowiae & 0.51 & 0.97 & 0.74 & $0.18 \mathrm{Ab}$ & $0.40 \mathrm{Aa}$ & 0.29 & $0.69 \mathrm{Ab}$ & $1.37 \mathrm{Aa}$ & 1.03 \\
\hline G. margarita & 0.55 & 0.66 & 0.60 & $0.20 \mathrm{Aa}$ & $0.26 \mathrm{Ba}$ & 0.23 & $0.75 \mathrm{Aa}$ & $0.92 \mathrm{Ba}$ & 0.83 \\
\hline G. rosea & 0.61 & 0.91 & 0.76 & $0.19 \mathrm{Ab}$ & $0.29 \mathrm{Ba}$ & 0.24 & $0.80 \mathrm{Ab}$ & $1.20 \mathrm{Aa}$ & 1.00 \\
\hline Mix & 0.48 & 0.80 & 0.64 & $0.15 \mathrm{Ab}$ & $0.30 \mathrm{Ba}$ & 0.23 & $0.63 \mathrm{Ab}$ & $1.10 \mathrm{Aa}$ & 0.87 \\
\hline Mean & $0.53 b$ & $0.8 \mathrm{Ia}$ & & 0.18 & 0.29 & & 0.71 & 1.02 & \\
\hline & \multicolumn{9}{|c|}{$\mathrm{F}$ (analysis of variance) } \\
\hline $\begin{array}{l}\text { Fungus } \\
\text { (F) }\end{array}$ & \multicolumn{2}{|r|}{$0.53 \mathrm{~ns}$} & \multicolumn{3}{|r|}{$1.90 \mathrm{~ns}$} & \multicolumn{3}{|r|}{$5.63^{*} *$} & \\
\hline $\begin{array}{c}\text { Condition } \\
\text { (C) }\end{array}$ & \multicolumn{2}{|r|}{$19.05 * *$} & \multicolumn{3}{|r|}{$54.30 * *$} & \multicolumn{3}{|r|}{$36.00 * *$} & \\
\hline $\mathrm{F} \times \mathrm{C}$ & & $0.55 n s$ & & & $3.00 *$ & & & $3.97 * *$ & \\
\hline $\begin{array}{l}\text { CV F } \\
(\%)\end{array}$ & \multicolumn{2}{|r|}{42} & \multicolumn{3}{|r|}{33} & \multicolumn{3}{|r|}{22} & \\
\hline $\begin{array}{l}\text { CV C } \\
(\%)\end{array}$ & \multicolumn{2}{|r|}{37} & \multicolumn{3}{|r|}{25} & \multicolumn{4}{|c|}{23} \\
\hline
\end{tabular}

(I)With stress; (2)without stress. SDM = shoot dry matter; RDM = root dry matter; $T D M=$ total dry matter; $C V$ = coefficient of variation. Means followed by the same uppercase letter in the column and lowercase letter in the row do not differ from each other by Scott-Knott test at $5 \%$ probability.

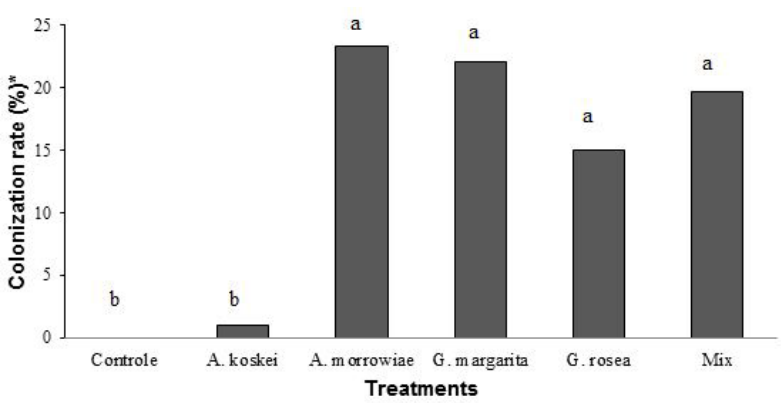

FIGURE 2 Mycorrhizal colonization rate in plants of Parkia platycephala inoculated with arbuscular mycorrhizal fungi (AMF) under water stress. *Data transformed into square root of $x+I$. Means followed by the same letter do not differ from each other by Scott-Knott test at $5 \%$ probability. 
Balota et al. (2010) and Brito et al. (2017) observed that the differential effect among AMF species occurs due to their ability to infect, colonize, and benefit the host plant and due to efficiency of absorbing P. In addition, when associated with host plants, AMF increase root surface area, giving the plant a higher capacity of water and nutrient absorption, favoring a higher growth and resistance rates.

According to the literature, our study presented a low colonization rate in plants of $P$. platycephala, which is in accordance with plants from the Caatinga biome, which reach around $50 \%$. In this sense, the species Mimosa sp. has a colonization rate ranging from 19 to $32 \%$ and Mimosa caesalpiniaefolia Benth. has a colonization rate from 36 to 54\% (Siqueira et al., 2010).

\section{Nutritional contents of the plant shoot}

In general, macro and micronutrients presented a decreasing order of $\mathrm{K}>\mathrm{Ca}>\mathrm{Mg}>\mathrm{P}$ and $\mathrm{Fe}>\mathrm{Zn}>\mathrm{Cu}>\mathrm{Mn}$, respectively. These data show the order of preference of nutrients by P. platycephala, being possible to reach more balanced fertilization (Table 4). For macro and micronutrient contents in the shoot of P. platycephala, an interaction was observed between strains and conditions (with and without water stress) in the contents of $\mathrm{P}, \mathrm{Mg}$, and $\mathrm{Mn}$ (Table 4).

The best results for $P$ were found in the treatments with $G$. rosea and inoculum of Mix under both stress condition, with an increase in $\mathrm{P}$ content from 236 to $282 \%$ under water stress in relation to the control (without inoculation). Under the condition without stress, the inoculation with these same strains showed an increase from 252 to $229 \%$ (Table 4).

Rodrigues et al. (2018) in an analogous study when evaluating the effect of inoculation of mycorrhizal fungi on the growth and mineral nutrition of Tectona grandis seedlings in unsterilized soil, observed the $\mathrm{P}$ content in the leaves of the uninoculated seedlings (control) were higher than in plants inoculated with the tested AMFs inoculants, differing from the present study.

Muller et al. (2017) assessed nutrient absorption in plants of Eucalyptus citriodora and $E$. grandis under different moisture regimes and observed that plants that underwent water stress had lower averages of macro and micronutrients accumulated in the shoot. In this case, nutrient availability was reduced in the soil solution when plants were under stress, which is in accordance with the results found in our study. In addition, soil solution volume is reduced, which reduces the absorption rate by plants under water stress due to a higher water tension retained in the micropores and a dependence of high energy expenditure on plants (Scalon et al., 20I I).

For $\mathrm{Mn}$ content, treatments did not differ from each other under stress condition. However, under the condition without stress, only the control differed from the other treatments. For $\mathrm{Mg}$ content, the inoculum Mix and the control (without inoculation) presented the highest values in relation to the condition without water stress (Table 4). According to Stürmer et al. (2009), fungal hyphae capture several mineral nutrients, which are used in the physiological process of plants.

The highest contents of $\mathrm{Cu}$ and $\mathrm{Fe}$ were found in plants under the condition without water stress, regardless of the treatments. For $\mathrm{Cu}$, the values found were 3.63 and $4.64 \mathrm{~g} \mathrm{~kg}^{-1}$ under the conditions of stress and without stress, respectively. For $\mathrm{Fe}$, the contents were $196.68 \mathrm{~g} \mathrm{~kg}^{-1}$ under stress condition and $237.77 \mathrm{~g}$ $\mathrm{kg}^{-1}$ without stress (Table 4). For Zn, no difference was observed for the studied water conditions. However, a difference was observed regarding treatments and the highest contents were observed in the strains $A$. morrowiae and $G$. rosea and in the inoculum Mix. No difference was observed in the contents of $\mathrm{K}$ and $\mathrm{Ca}$ regarding the different treatments under the assessed water conditions (Table 4).

Saboya et al. (20I2) assessed the production of seedlings of Jatropha curcas L. inoculated with Scutellospora calospora, Glomus clarum, G. margarita, A. morrowiae, and mycorrhizal species (Mix) and observed that the contents of micronutrients in the plant shoot did not present significant differences for $\mathrm{Fe}$ and $\mathrm{Zn}$. This result differs from that found in our study in relation to $\mathrm{Zn}$, which presented a difference between treatments with inoculation. The authors observed that $\mathrm{Mn}$ and $\mathrm{Mg}$ contents presented better results when plants were inoculated with the strain $A$. morrowiae even without full fertilization, showing the efficiency of AMF even with the inoculation in isolation.

According to Miranda et al. (2008) and Faria et al. (20I3), AMF maximize the absorption efficiency of low-mobility nutrients in the soil, especially $\mathrm{P}$ and $\mathrm{Zn}$, making them more available to plants, reaching the roots through the diffusion process and allowing plant growth even in extremely poor soils.

Information on the mycorrhizal association with P. platycephala and the relationship with edaphoclimatic conditions in the Cerrado-Caatinga transition area is still limited. However, the data obtained in this study can be used in further studies, being important for the interest and motivation in the sustainable agricultural system. 
TABLE 4 Macro and micronutrients in seedlings of Parkia platycephala inoculated with arbuscular mycorrhizal fungi (AMF) under water stress.

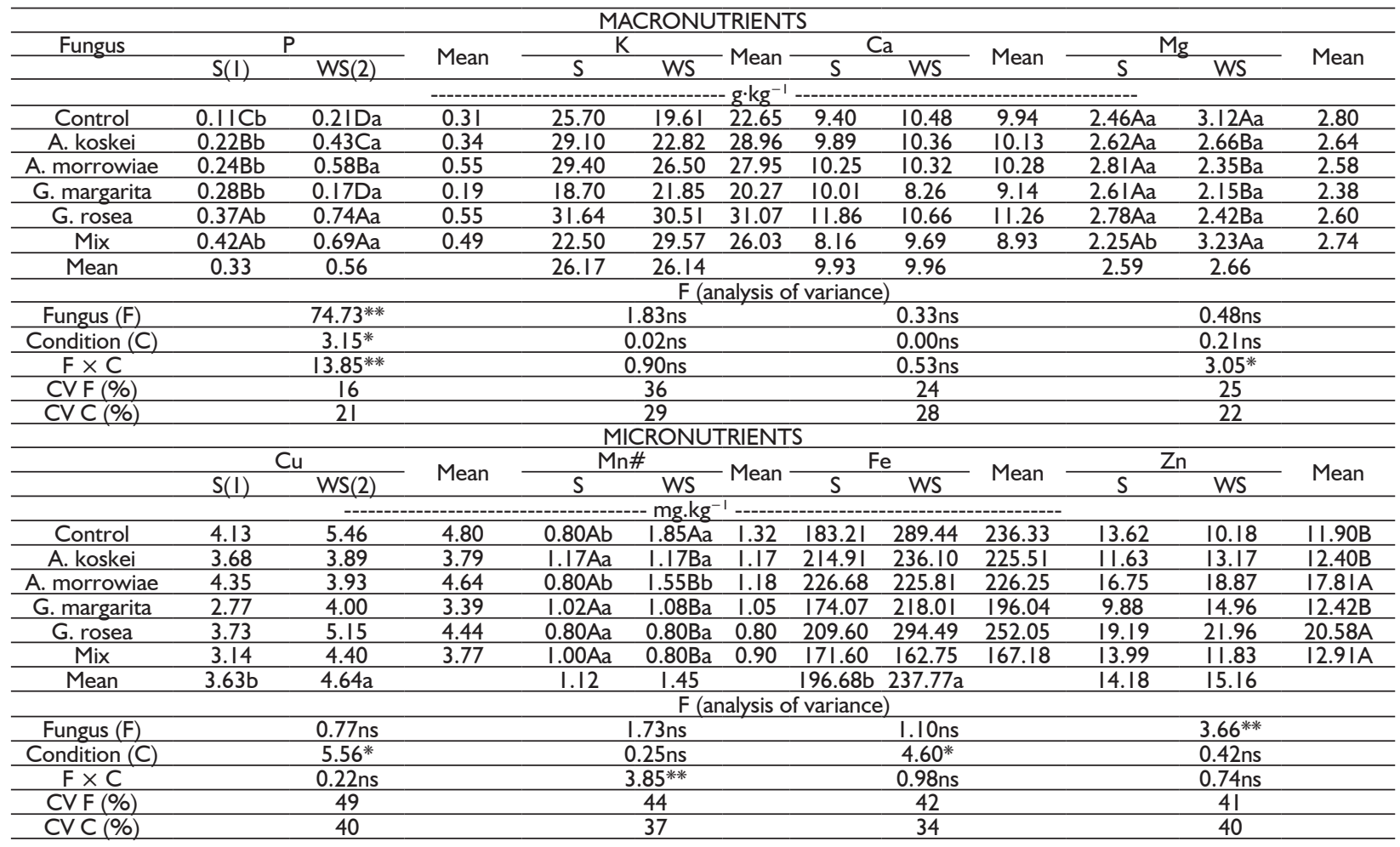

(')With stress; ${ }^{(2)}$ without stress. $\mathrm{P}=$ phosphorus; $\mathrm{K}=$ potassium; $\mathrm{Ca}=$ calcium; $\mathrm{Mg}=$ magnesium; $\mathrm{Cu}=$ copper; $\mathrm{Mn}=\mathrm{Manganese}$; Fe = iron; $\mathrm{Zn}=$ zinc; $\mathrm{CV}=\mathrm{co}-$ efficient of variation. Means followed by the same uppercase letter in the column and lowercase letter in the row do not differ from each other by Scott-Knott test at $5 \%$ probability. \#Data transformed into square root of $x+1$.

\section{CONCLUSION}

The morphological variables plant height, stem diameter, and shoot dry matter of plants presented a reduction when submitted to water stress. In addition, an interaction was observed between AMF and the studied water condition for the variables number of leaves, root dry matter, and total dry matter.

Plants with water stress presented a lower absorption of macro and micronutrients in relation to the condition without stress. An interaction was observed for $\mathrm{P}, \mathrm{Mg}$, and $\mathrm{Mn}$. The inoculation with mycorrhizal fungi provided a difference in $\mathrm{Zn}$ contents in the leaves of $P$. platycephala.

The mycorrhizal colonization rate of P. platycephala was influenced by AMF regardless of water conditions, being considered low at I 20 days of cultivation under the studied conditions.

\section{ACKNOWLEDGEMENTS}

To the Coordination for the Improvement of Higher Education Personnel (Capes) and the Federal University of Piauí (UFPI) for financial support and collaboration in this study.

To the Regional University of Blumenau (FURB) for donate the arbuscular mycorrhizal fungi strains.

\section{REFERENCES}

ALVAREZ, WH; RIBEIRO, AC. Recomendações para o uso de corretivos e fertilizantes em Minas Gerais. In: RIBEIRO, AC. et al. UFV, I999. p. 43-60.

BORGES, AJS; TRINDADE, AV; MATOS, AP; PEIXOTO, MFS. Reduction of fusarium wilt of "banana-maçã" by inoculation of arbuscular mycorrhizal fungi. Pesquisa Agropecuária Brasileira, v. 42, n. I, p. 35-4I, 2007.

BRITO, VN; TELLECHEA, FRF; HEITOR, LC; FREITAS, MSM; MARTINS, MA. Fungos micorrízicos arbusculares e adubação fosfatada na produção de mudas de Paricá. Ciência Florestal, v. 27, n. 2, p. 485-497, 2017.

CANEIRO, RFV; JÚNIOR, FMC; ARAÚJO, ASF; FILHO, CHAR; SOUSA, RF. Atributos dos fungos micorrízicos arbusculares como indicadores de áreas degradadas e em recuperação no estado do Piauí. Revista Brasileira de Agroecologia, v. II, n. 2, p. 6I-69, 2016.

COSTA, AS; FREIRE, ALO; BAKKE, IA; PEREIRA, FHF. Respostas fisiológicas e bioquímicas de plantas de aroeira (myracrodruon urundeuva allemão) ao déficit hídrico e posterior recuperação. Irriga, v. 20, n. 4, p. 705-7I 7, 2015.

DUARTE, EA; FILHO, PAM.; SANTOS, RC. Características agronômicas e índice de colheita de diferentes genótipos de amendoim submetidos a estresse hídrico. Revista Brasileira de Engenharia Agrícola e Ambiental, v. I7, n. 8, p. 843-847, 2013. 
EMBRAPA. Manual de análises químicas de solos, plantas e fertilizantes. Embrapa Informação Tecnológica, 2009. 627 p.

FARIA, MT; SCABORA, MH; MALTONI, KL; CASSIOLATO, AMR. Micorrização e crescimento de progênies de Hymenaea stignocarpa Mart. ex. Hayne em subsolo de área degradada. Ciência Florestal, v. 23, n. I, p. 233-243, 2013.

FARIAS, SGG; FREIRE, ALO; SANTOS, DR; SILVA, RB; FREIRE, JLO. Respostas de plantas de Moringa (Moringa oleifera Lam.) inoculadas com fungos micorrízicos e submetidos ao estresse hídrico. Engenharia Ambiental, v. 5, n. 3, p. 3646, 2008.

FOLLI-PEREIRA, MS; MEIRA-HADDAD, LSA; BAZZOLLI, DMS; KASUYA, MSM. Micorriza arbuscular e a tolerância das plantas ao estresse. Revista Brasileira de Ciência do Solo, v. 36, n. 6, p. 1663-1679, 2012.

FOOD AND AGRICULTURE ORGANIZATION OF THE UNITED NATIONS. Disponível em: http://www.fao.org/3/ a-ai822e.pdf. Acesso em: 15 de Novembro de 2018.

GIOVANNETTI, M; MOSSE, B. An evaluation of techniques for measuring vesicular arbuscular mycorrhizal infection in roots. New Phytologist, v. 84, n. 3, p. 489-500, 1980.

INSTITUITO BRASILEIRO DE GEOGRAFIA E ESTATÍSTICA. Disponível em https://ww2.ibge.gov.br/home/presidencia/ noticias/21052004biomashtml.shtm. Acesso em: 15 de Novembro de 2018.

KOSKE, RE.; GEMMA, JNA. Modified procedure to detect mycorrhizas. Mycological Research, v. 92, n. 4, p. 486488, 1989.

LORENZI, H. Árvores brasileiras: manual de identificação e cultivo de plantas arbóreas nativas do Brasil. Nova Odessa: Instituto Plantarum, 2002. 174p.

MARTINS, FB.; STRECK, NA.; SILVA, JC; MORAIS, WW.; SUSIN, F; NAVROSKI, MC.; VIVIAN, MA. Deficiência hídrica no solo e seu efeito sobre transpiração, crescimento e desenvolvimento de mudas de duas espécies de eucalipto. Revista Brasileira de Ciência do Solo, v. 32, p. 1297 1306, 2008.

MATOS, FS; FREITAS, IAS; SOUZA, BR; LOPES, VA; ROSA, VR. Crescimento de plantas de Tectona grandis sob restrição hídrica. Agrarian, v. II, n. 39, p. I4-21, 2018a.

MATOS, F; FREITAS, IAS; SANTOS, LVB; VENÂNCIO, DG; SILVEIRA, PA. Initial growth of Dipteryx alata plants under water deficit. Revista Árvore, v. 42, n. I, $2018 \mathrm{~b}$.

MAZZUCHELLI, EHL.; SOUZA, GM.; PACHECO, AC. Rustificação de mudas de eucalipto via aplicação de ácido salicílico. Pesquisa Agropecuária Tropical, v. 44, n. 4, p. 443-450, 2014
MEDEIROS, RM.; SILVA, VMAde., MELO, VSda., MENEZES, HEA; MENEZES, HEA. Diagnóstico e tendência da precipitação pluvial em Bom Jesus- Piaú, Brasil. Revista Verde de Agroecologia e Desenvolvimento Sustentável, v. II, n. 3, p. II5-I2I, 2016.

MINISTÉRIO DO MEIO AMBIENTE. Bioma Caatinga. Disponível em: http://www.mma.gov.br/biomas/caatinga. Acesso em: 10 maio 2018.

MINISTÉRIO DO MEIO AMBIENTE. Bioma Cerrado. Disponível em: http://www.mma.gov.br/biomas/cerrado. html. Acesso em: 10 maio 2018.

MIRANDA, JCC. Cerrado: Micorriza arbuscular ocorrência e manejo. Embrapa Cerrados, 2008. 169p.

MULLER, C.; HODECKER, BER.; MERCHANT, A.; BARROS, NF. Nutritional Efficiency of Eucalyptus Clones Under Water Stress. Revista Brasileira de Ciência do Solo, v. 4I, n. e0I60528, p. I-I7, 2017.

NADEEM, SM; AHMAD, M; ZAHIR, ZA; ASHRAF, M. The role of mycorrhizae and plant growth promoting rhizobacteria (PGPR) in improving crop productivity under stressful environments. Biotechnology advances, New York, v. 32 , n. 2, p. 429-448, 2014 .

NASCIMENTO, IL; ALVES, EU; BRUNO, RLA; GONÇALVES, EP; COLARES, PNQ; MEDEIROS, MS. Superação da dormência em sementes de Faveira (Parkia platycephala Benth). Revista Árvore, v. 33, n. I, p. 35-45, 2009.

NUNES, JLS; SOUZA, PVD; MARODIN, GAB; FACHINELLO, JC. Inoculação de fungos micorrizicos arbusculares em portaenxerto de pessegueiro Cv okinawa. Revista Brasileira de Fruticultura, v. 30, n. 4, p. II00-II06, 2008.

OLIVEIRA, TM; ALVES, AR; AMARAL, CG, ALMEIDA, KND; SOUZA, KB; AGUIAR, AS; ARAÚJO, EF. FARIAS, SGG. Análise da estrutura vegetacional em uma área de transição Cerrado-Caatinga no município de Bom Jesus-PI. Scientia Plena, v. 8, n. 4, 2012.

PELEGRINI, LL; BORCIONI, E; NOGUEIRA, AC; KOEHLER; QUOIRIN, MGG. Efeito do estresse hídrico simulado com $\mathrm{NaCl}$, manitol e PEG (6000) na germinação de sementes de Erythrina falcata Benth. Ciência Florestal, v. 23, n. 2, p. 5||$-5|9,20| 3$.

PEREIRA, JWL; FILHO, PAM; ALBUQUERQUE, MB; NOGUEIRA, RJMC; SANTOS, RC. Mudanças bioquímicas em genótipos de Amendoim submetidos a déficit hídrico moderado. Revista Ciência Agronômica, v. 43, n. 04, p. 766-773, 2012.

R CORE TEAM (2016). R: A language and environment for statistical computing. R Foundation for Statistical Computing, Vienna, Austria. URL https://www.R-project.org/.

RODRIGUES, LA., BARROSO, DG., FIQUEIREDO, FAMM de A. Fungos micorrízicos arbusculares no crescimento e na nutrição mineral de mudas de Tectona grandis L.F. Revista Ciência Florestal, v. 28, n. I, p. 25-34, 2018. 
SABOYA, RCC; JÚNIOR, AFC; MONETIRO, FPR; SANTOS GR; ERASMO, EAL; CHAGAS, LFB. Fungos micorrízicos arbusculares afetando a produção de mudas de Pinhãomanso na região Sul do Estado de Tocantins, Brasil. Revista Ceres, v. 59, n. I, p. I42-146, 2012.

SANTOS, HGdos; JACOMINE, PKT; ANJOS, LHCdos; OLIVEIRA, VAde; LUMBRERAS, JF; COELHO, MR; ALMEIDA, JAde; CUNHA, TJF; OLIVEIRA, JBde. Sistema Brasileiro de Classificação de Solos. Embrapa Solos. 2013. 353p.

SCALON, SPQ; MUSSURY, RM; EUZÉBIO, VLMde; KODAMA, FM; KISSMANN, C. Estresse hídrico no metabolismo de crescimento inicial de mudas de Mutambo (Guazuma ulmifolia Lam.). Ciência Florestal, v. 2I, n. 4. p. 655-662, 201 I.

SILVA, RB; MATOS, VP; FARIAS, SGGde; SENA, LHM de; SILVA, DYOde. Germinação e vigor de plântulas de Parkia platycephala Benth. em diferentes substratos e temperaturas. Revista Ciência Agronômica, v. 48, n. I, p. I42-150, 2017.

SILVA, CF; ARAÚJO, JLS; SILVA, EMRda; PEREIRA, MG; FREITAS, MSM; JÚNIOR, OJS; MARTINS, MA. Fungos micorrízicos arbusculares e proteína do solo relacionada à glomalina em área degradada por extração de argila e revegetada com eucalipto e acácia. Ciência Florestal, v. 22, n. 4, p. 749-76I, 2012.

SILVA, MA; CAVALCANTE, UMT; SILVA, FSBda; SOARES, SAG; MAIA, LC. Crescimento de mudas de Maracujazeiro-doce (Passiflora alata Curtis) associados a fungos micorrízicos arbusculares (Glomeromycota). Acta Botânica Brasilica, v. I8, n. 4, p. 98I-985, 2004.

SILVEIRA, OS; CUSTÓDIO, JPC; SILVA, FCMda; NASCENTE, ACSde; MONTEIRO, CL; MATOS, FS. A ação dos brassinosteróides no crescimento de mudas de Pinhão manso sob déficit hídrico. Agriculture environmental sciences, v. 2, n. I, p. 52-6I, 2016.

SOARES, ACF; SOUSA, CSda; GARRIDO, MSda; LIMA, FSde. Fungos micorrízicos arbusculares no crescimento e nutrição de mudas de Jenipapeiro. Revista Ciência Agronômica, v. 43 , n. I, p. 47-54, 2012.
SOARES, CRFS; CARNEIRO, MAC. Micorrizas arbusculares na recuperação de áreas degradadas. In: SIQUEIRA, J. O. Micorrizas: $\mathbf{3 0}$ anos de pesquisa no Brasil. UFLA, 20I0. p. 44 I-474.

SOUSA, DMG; LOBATO, E (Ed.). Cerrado: correção do solo e adubação. Embrapa Informação Tecnológicas, 2004. $416 p$.

STÜRMER, SL; SIQUEIRA, JO. Species richness and spore abundance of arbuscular ycorrhizal fungi across distinct land uses in Western Brazilian Amazon. Mycorrhiza, v. 21 , n. 4 , p. $255-267,201$ I.

SUGAI, MAA., COLLIER, LS., SAGGIN-JÚNIOR, OJ. Inoculação micorrízica no crescimento de mudas de Angico em solo de cerrado. Revista Bragantia, v. 70, n. 2, p. 4I6-423, 20 I I.

TAIZ, L; MOLLER, EZM; MURPHY, A. Fisiologia e Desenvolvimento Vegetal. Artmed, 2017. 857p.

THORNTHWAITE, CW. An approach towards a rational classification of climate. Geographical Review, v. 38, n. I, p. 55-94, 1948.

UPADHYAY, HD; SHARMA, S; SUBE, S; SINGH, M. Inheritance of drought resistance related traits in two crosses of groundnut (Arachis hypogaea L.). Euphytica, v. I77, n. I, p. 55- 66, 2011 .

WRIGHT, SF; UPADHYAYA, A. Extraction of an abundant and unusual protein from soil and comparison with hyphal protein of arbuscular mycorrhizal fungi. Soil Science, v. 161 , n. 9 , p. $575-58,1996$.

WRIGHT, SF; UPADHYAYA, A. A survey of soils for aggregate stability and glomalin, a glycoprotein produced by hyphae of arbuscular mycorrhizal fungi. Plant Soil, v. 198, n. I, p. 97-107, 1998.

WRIGHT, SF; FRANKE-SNDER, M; MORTON, JB; UPADHYAYA, A. Time-course study and partial characterization of a protein on hyphae of arbuscular mycorrhizal fungi during active colonization of roots. Plant Soil, v. I8I, n. 2, p. 193-203, 1996. 